IZA DP No. 9438

The Use and Impact of Job Search Procedures by Migrant Workers in China

Tony Fang

Morley Gunderson

Carl Lin

October 2015 


\title{
The Use and Impact of Job Search Procedures by Migrant Workers in China
}

\author{
Tony Fang \\ Memorial University of Newfoundland, Monash University, \\ University of Toronto, Rutgers University and IZA \\ Morley Gunderson \\ University of Toronto \\ Carl Lin \\ Bucknell University, \\ IZA and China Institute for Income Distribution
}

Discussion Paper No. 9438

October 2015

\author{
IZA \\ P.O. Box 7240 \\ 53072 Bonn \\ Germany \\ Phone: $+49-228-3894-0$ \\ Fax: +49-228-3894-180 \\ E-mail: iza@iza.org
}

Any opinions expressed here are those of the author(s) and not those of IZA. Research published in this series may include views on policy, but the institute itself takes no institutional policy positions. The IZA research network is committed to the IZA Guiding Principles of Research Integrity.

The Institute for the Study of Labor (IZA) in Bonn is a local and virtual international research center and a place of communication between science, politics and business. IZA is an independent nonprofit organization supported by Deutsche Post Foundation. The center is associated with the University of Bonn and offers a stimulating research environment through its international network, workshops and conferences, data service, project support, research visits and doctoral program. IZA engages in (i) original and internationally competitive research in all fields of labor economics, (ii) development of policy concepts, and (iii) dissemination of research results and concepts to the interested public.

IZA Discussion Papers often represent preliminary work and are circulated to encourage discussion. Citation of such a paper should account for its provisional character. A revised version may be available directly from the author. 


\section{ABSTRACT \\ The Use and Impact of Job Search Procedures by Migrant Workers in China*}

Job search procedures are a form of human capital investment in that they involve current investments to enhance future returns, analogous to human capital investments in areas such as education, training and mobility that yield future returns. While the theoretical and empirical literature on job search is extensive, most of it involves developed countries. There is less on developing countries and very little on China involving migrant workers in spite of their growing practical and policy importance and the fact that they are constantly engaging in job search. This paper examines the use and impact of job search procedures used by migrant workers in China by taking advantage of a rich data set on migrant workers that has information on their job search procedure as well as a wide array of other personal and human capital characteristics. Our OLS estimates indicate that there is no effect on earnings of using informal versus formal job search procedures for migrant workers in China. However, our IV results suggest that the OLS estimates are subject to severe selection bias from the fact that the choice of job search procedure is endogenous, associated with unobservable factors that affect the choice of informal versus formal procedures and that affect the earnings outcome. Our three different IV estimates designed to deal with this bias indicate that informal procedures (various aspects of family and friends) are associated with earnings that are 33 to 43 percent below the uses of more formal procedures. The decomposition results indicate that the most important variable contributing to pay advantage of those who use formal as opposed to informal procedures is education. In sum, our results suggest that policies to encourage or facilitate migrant workers using more formal job search procedures and reducing barriers that compel them to rely on informal procedures can yield better job matches with higher earnings.

JEL Classification: J31, J61, J64

Keywords: job search methods, migrant workers, labour market outcomes, China

Corresponding author:

Carl Lin

236 Academic West

Department of Economics

Bucknell University

1 Dent Drive

Lewisburg, PA 17837

USA

E-mail: carl.lin@bucknell.edu 


\section{THE USE AND IMPACT OF JOB SEARCH PROCEDURES BY MIGRANT WORKERS IN CHINA}

\section{Introduction}

Job search procedures are a form of human capital investment in that they involve current investments (time and money) to enhance future returns. In that vein, they are analogous to human capital investments in areas such as education, training and mobility that yield future returns. Informal search procedures can also involve reciprocal social capital exchanges, although the quality of that information can depend upon who provides the information (Giulietti, Wahba and Zenou 2014). Low quality networks can foster low quality job searches.

While the theoretical and empirical literature on job search is extensive, most of it involves developed countries. ${ }^{1}$ There is less on developing countries ${ }^{2}$ and very little on China involving migrant workers in spite of their growing importance and the fact that they are constantly engaging in job search. ${ }^{3}$

The issue of the job search of migrant workers in China is of practical and policy importance for a variety of reasons. From the employer's perspective, migrant workers constitute a substantial component of the labour force in China. The 2000 population Census, for example, indicated that 144.39 million rural residents or 11.6 percent of the total population moved into cities and towns (Lu and Song, 2006, p.338). This has been described as "the largest domestic migration flow in human history" (Qu and Zhao, 2011, p. 1). Such migrant workers are a key

\footnotetext{
${ }^{1}$ Studies that contain reviews of the extensive literature include Mortensen (1986), Saks (2005) and Schwab, Rynes and Aldag (1987).

${ }^{2}$ Downs, A. \& Gunderson, M. (2002) review the literature on developing countries.

${ }^{3}$ Wang (2008) compares the job search of rural versus non-rural hukou, but the analysis is restricted to university graduates. Chen (2014) examines the job search methods of migrants, but the analysis is restricted to migrant workers into Shanghai. Hanser (2002) examines the choice of job search methods, but the analysis is restricted to young urbanites and based on interviews. The closest paper to ours is Long et. al. (2013) who compare informal and formal search methods and finds, as we do, that informal networks yield lower earnings after correcting for selection bias.
} 
component of filling labour shortages that can otherwise lead to production bottlenecks that can jeopardize competitiveness and macro-economic stability. Better job matches can also provide the flexibility to meet rapidly changing market demands and the pursuit of profits, often at the expense of more permanent workers, especially in State Owned Enterprises (Solinger 1999, Xu $2000,2012)^{4}$

From the perspective of migrant workers themselves, an effective job search procedure increases their opportunities and reduces their vulnerability to exploitation. It can obviously enhance their earnings which in turn can be important for remittances and poverty reduction. By definition of being a migrant worker, job search is especially important since they are continuously engaging in job search. This is especially the case given the enhanced emphasis on individual responsibility for obtaining job in China's increasingly flexible labour market. As stated by Xu (2012, p. 42): "Ultimately individuals have to rely on themselves in navigating this new labour market.” Job search procedures are obviously important in such navigation.

From the perspective of the government, an effective job search procedure can reduce any social instability that may arise if migrant workers are not able to obtain jobs that match their ability and skills. Effective job matches can also enhance the productivity and competitiveness that is essential to sustaining high growth rates. Governments in China are increasingly putting pressure on the unemployed to actively seek work, so that effective job search methods become increasingly important. As aptly stated by Xu (2012, p. 3): “As reflected in the government's

\footnotetext{
${ }^{4}$ We have also investigated how the informal job searching methods affect migrant workers' type of contracts (permanent, long-term, short-term, and no-contract temporary). We report the summary statistics in Appendix Table 1 and the multinomial logit estimates in Appendix Table 2. The summary statistics show that, relative to the other three types of contract, long-term contract migrant workers have highest average earnings and years of schooling, received more training, and have more people with unemployment insurance. In contrast, no-contract temporary workers are more likely to use informal job search methods (66\%), compared to permanent (58\%), long-term (56\%), and short-term contract workers (60\%). The multinomial logit results in Appendix Table 2 indicate that, relative to permanent contract workers, migrants who use informal methods to search jobs are more likely to become shortterm contract or no-contract temporary workers. In contrast, there is no statistically significant effect of job search methods on long-term contract workers.
} 
active employment policy, the market remains the main driving mechanism for solving unemployment ....New organizations and institutions [to facilitate job search] ... include public and private employment agencies"

The purpose of this paper is to examine the use and impact of job search procedures used by migrant workers in China. As detailed subsequently, we take advantage of a rich data set on migrant workers in China that has information on their job search procedure as well as a wide array of other personal and human capital characteristics. The next section of the paper sets out our conceptual framework followed by our empirical methodology and a description of the data set. A discussion of our results follows, and the paper ends with some concluding observations.

\section{Conceptual Framework}

While job search models can be formidable in their complexity, they essentially involve the process where workers obtain information on potential job offers as well as job search strategies. There is a trade-off between the cost of additional time, effort and resources spent in searching, including through using different search procedures, and the benefits that such additional search should yield. Different search procedures have different costs and benefits associated with them, and these costs and benefits may vary across different workers.

Informal procedures, generally termed "family and friends" in the job search literature may involve little cost for both job seekers (Rees 1966) and employers (Fernandez, Castilla and Moore 2000). Also, they may be particularly effective in yielding a good match to the extent that family and friends have good information on both the employee and employer sides of the market, and friendships and reputations may be at stake as part of reciprocal social capital exchanges (Holzer 1988). However, the effectiveness of such informal procedures depends on the quality of the informal networks involved with family and friends (Fang et. al. 2013; 
Giulietti, Wahba and Zenou 2014; Granovetter 1973). People who are similar to each other are likely to become friends (Mouw 2003) and if those social networks are not well informed about good job possibilities, as can be the case with rural migrant workers in China (Chen 2014; Long et. al. 2013), they may yield poor quality job matches with low earnings.

Formal job search procedures may be more costly in terms of fees and time and effort for both job seekers and employers. But they may be more effective in terms of yielding better matches because of vetting and targeting. For example, direct applications for advertised positions or through contacting firms directly may involve some additional time and effort on the part of individuals to target potential better matches, and they can also involve more of a "shotgun" approach with the hope that sufficient contacts will generate an offer even if there are many refusals or non-responses (Kahn and Low 1990). Using a private employment service can involve additional costs but can yield benefits from the vetting and targeting provided by such a service. In contrast, public employment agencies don't involve a fee, but they are often regarded as ineffective because they do not serve a matching role outside of posting jobs and job seekers (Addison 2002, Blau and Robbins 1990, Holzer 1988, Martin and Grubb 2001, Osberg 2003). Increasingly, the internet is regarded as an important job search mechanism (Kuhn and Skuterud 2004; Stevenson 2009) albeit migrant workers in China are not likely to have access to the internet.

Of particular potential relevance to migrant workers in China, are the job-search models like those of Black (1995), Blackaby, Booth and Frank (2005), Bowlus (1997) and Lai and Tian (2005). These models emphasize that the job search of particular groups may be limited by social ties to the household and local community. Such ties to their household in their home base can limit their search. This reduction in the scope of their job search limits their job offers and 
reduces their reservation wage at which they would accept an offer. This framework also focuses on barriers to job search and mobility and hence can highlight the policy options for facilitating effective job search.

Our empirical results will be interpreted through the lens of these different job search models. Of particular relevance to migrant workers, the different procedures are potentially endogenous in that they may be selected or used by the different groups based on unobservable factors that can affect outcomes (Long et al., 2013). It is not feasible to utilize conventional instrumental variable analyses to provide causal estimates of the effect of each separate search procedure since it requires a separate instrument for each potentially endogenous variable (i.e., each different search procedure, and our data set involves 12 search procedures). To circumvent this problem we group the specific job search procedures into formal or informal procedures (discussed subsequently) and use instruments for the use of informal procedures. A major focus of our paper is to compare conventional OLS estimates of the effect of informal versus formal job search procedures which may be subject to selection bias, with Instrumental Variable (IV) estimates that deal with the selection bias.

\section{Empirical Methods}

We first estimate a conventional OLS regression of the natural $\log (\ln )$ of monthly earnings in their current job on a dummy variable reflecting whether they found the job using informal compared to formal job search procedures (defined subsequently). We also include a set of control variable that can also affect earnings.

The mean values of the job search procedures (reported in Table 1) indicate the extent to which each of the procedures is used. The regression coefficients (reported in Table 2) indicate the effectiveness of the procedures in terms of their impact on the earnings outcome. 
To deal with the potential selection bias that may occur because the choice of informal versus formal search procedures may be endogenous and reflect unobserved factors that may also affect the earnings outcome, we also employ various Instrumental Variable procedures (also reported in Table 2). We use Two-Staged-Least Squares (2SLS) to instrument the informal job search procedure with two instruments. The first instrument, "helpers" is anyone, who had helped you in the past 12 months, including lending money to you, helped finding a job, taking care of a child, or talking and giving advice. This IV reflects social networks that should help migrants expand their job search to use more formal methods and rely on fewer informal ones, but not directly affect migrants' earnings -- more precisely, "helpers" is uncorrelated with the error term of the earnings equation. The first-stage regression shows this to be the case in that the coefficients of helpers in predicting the use of informal methods is negative and highly significant $(-0.0015(0.0004)) .{ }^{5}$ Our second instrument, "people greeted living in the city" denotes the number of persons, currently living in the city, to whom you sent your greetings in various ways (including visiting/phone call/mail/e-mail, etc.) during the past China Lunar New Year. It has a similar rationale of indicating social networks that should help migrants expand their job search to use more formal methods and rely on fewer informal ones. Again the firststage regression confirms this, with the coefficient of "people greeted" on predicting the use of informal methods being negative and highly significant (-0.0015(0.0005)).

To address any weak instrument concern ${ }^{6}$, we also use a Limited Information Maximum Likelihood (LIML) estimator which is asymptotically equivalent to 2SLS and has been found to

\footnotetext{
${ }^{5}$ Nevertheless, we are aware that helpers may also introduce jobs and serve as informal channel which result in weak instrument incidents. We discuss the issue in footnotes 6 and 7.

${ }^{6}$ Our F-statistic for the first-stage is 9.319 which is slightly below the value of 10 that is generally regarded as the critical value for a viable instrument, suggesting that we might have weak instrument issues.
} 
outperform both 2SLS and Optimal Generalized Method of Moments (GMM) in finite samples. ${ }^{7}$ We also estimate separate regressions for those who used formal procedures and those who used informal ones. This enables us to decompose the mean earnings differential between those who used formal procedures compared to informal ones into two component parts: differences in the usage of the job search procedures (their mean values) and differences in their effect on earnings (coefficients).

This can be illustrated with the procedure outlined in Oaxaca (1973). That is, estimation of the separate earnings equations enables decomposing the mean earnings difference $\left(\bar{Y}_{f}-\bar{Y}_{i}\right)$ between those who use formal procedures and those who use informal ones (denoted respectively by the subscript $\mathrm{f}$ and i) into two components:

$$
\left(\bar{Y}_{f}-\bar{Y}_{i}\right)_{=}\left(\bar{X}_{i}-\bar{X}_{f}\right) \beta_{f+}\left(\beta_{f}-\beta_{i}\right) \bar{X}_{i}
$$

The first component represents differences in their observable characteristics or explanatory variables $\left(\bar{X}_{f}-\bar{X}_{i}\right)$ that influence the outcomes. In the case of job search procedures they represent the usage of the different procedures by males and females. They are weighted by the returns or effect on wages, $\beta_{\mathrm{f}}$, that are received for those characteristics. ${ }^{8}$ The second component

\footnotetext{
${ }^{7}$ Based on the Sargan-Hansen test of over-identifying restrictions, in the three IV methods (2SLS, LIML and GMM) we do not reject the null hypothesis that the instrumental variables are uncorrelated with the residuals of the earnings equation. Although the first-stage F statistics of 9.319 might signal the weak instrument issue, for LIML, our weak identification test in Table 2 reports Cragg-Donald Wald F statistic which is significant at 10\% for Stock and Yogo (2005) maximal IV size with critical value of 8.68. Therefore, we consider our instruments as valid and LIML substantially reduces the concern of weak instruments (Murray 2006).

${ }^{8}$ Different weights or coefficients can be used to evaluate or weight the differences in outcome determining characteristics (van der Muelen Rodgers 2006; Jann 2008). We present the results from the commonly used Oaxaca and Ransom (1994) procedure Our results are not sensitive to using the weights or returns from other procedures such as the coefficients of both groups weighted by the group sizes (Cotton, 1988) or the coefficients from a pooled regression over both groups (Neumark, 1988).
} 
of differences in the regression coefficients reflects differences in these returns or effect on the outcomes, $\left(\beta_{f}-\beta_{i}\right)$ from the same characteristics.

In the conventional decomposition it is possible to sub-decompose the characteristics or usage component into various sub-components that reflect the relative contribution of each explanatory variable to the characteristics component. However, it is not possible to subdecompose the coefficients or effect component since their relative contribution is not invariant to the choice of the omitted reference category when categorical variables are used (Jann 2008). However, the estimation equations can be set up so that the coefficients are interpreted as deviations from the grand mean so that sub-decomposition analyses can be conducted on both components so as to determine the relative importance of each of the separate variables in contributing to the portion of the gap explained by the different usages of the job search procedures and the portion attributable to different effects of the procedures. We apply the normalization method in Yun (2005) and Gardeazabal and Ugidos (2004) to address the identification problem that detailed coefficients effects attributed to the dummy variables are not invariant to the choice of the omitted reference. This enables making statements about the relative importance, in explaining how earnings differences between those who use formal versus informal procedures reflect differences in their usage of different job search procedures, $\left(\bar{X}_{f}-\bar{X}_{i}\right)$ and differences in the effectiveness of each procedure, $\left(\beta_{f}-\beta_{i}\right)$ in terms of how they affect earnings.

\section{Data}

Our data is based on the Rural-to-Urban Migrants Surveys for 2008 and 2009 from the Longitudinal Survey on Rural Urban Migration in China (RUMiC). RUMiC was set up to investigate the patterns and effects of migration in China. It involves individual microdata 
jointly collected by researchers at the Australian National University (ANU), the University of Queensland and the Beijing Normal University (BNU). The data was supported by the Institute for the Study of Labor (IZA) where IZA provides the Scientific Use Files through its data center.

The survey is ideally suited for our purpose because it contains detailed information on the job finding method used to find the subsequent job that was obtained through the search procedure. The information is based on the survey question: How did you get this last/current job, before returning to your hometown? The responses are mutually exclusive and can be naturally grouped into informal procedures (family members, relatives, friends and acquaintances) as well formal procedures (public employment agency ${ }^{9}$ private commercial employment agency, including job fairs; applied for advertised job, including through the internet; applied directly (including through examination); employer recruitment; and other (includes found the job by himself, internship introduced by school, introduced by the school, and continued to hold the old job).

As indicated, such an aggregation is necessary for us to employ Instrumental Variable procedures to deal with potential selection bias from the fact that the choice of search procedure is endogenous. It also reduces the measurement error that can result from the uncertainty the respondent may have as to the appropriate category to designate.

The survey also contains comprehensive information on a wide array of control variables that can also affect the earnings outcome. These control variables include years of schooling, age, training received, gender, marital status, health, physical disability, hukou status, covered by

\footnotetext{
${ }^{9}$ Public employment agency includes the job being assigned by the government, an agency run by government, or a community employment service station.
} 
unemployment insurance, ${ }^{10}$ as well as industry, occupation and region. The three regions cover 15 cities which are either provincial capital cities or other major migrant receiving cities. The Eastern region contains Guangzhou, Dongguan, Shenzhen, Shanghai, Nanjing, Wuxi, Hangzhou, and Ningbo; the Central region includes Zhengzhou, Hefei, Luoyang, Bengbu, and Wuhan; and the Western region surveys the two important cities in the inland of China: Chengdu and Chongqing.

We restrict our analysis to individuals who are age 16-64, full-time wage workers and report positive earnings. Self-employed, temporary jobs, part-time workers, students still in school, and family business helpers are excluded. To reduce the effect from outliers, we also exclude workers whose monthly earnings are less than $100 \mathrm{rmb}$ or greater than $20,000 \mathrm{rmb}$. After cleaning missing values, our pooled dataset contains 8,155 individuals (4,839 for 2008 and 3,316 for 2009). Earnings has been adjusted for inflation and accounted for the differing living costs among provinces by applying the PPP-adjusted deflator developed by Brandt and Holz (2006). ${ }^{11}$

Our paper is complementary to Long et al. (2013) who use the same data set. The main differences are: they use 2008 data and we use both 2008 and 2009 data $^{12}$; they use a switching regression model to control for selection bias, while we use a variety of procedures including Two-Staged Least Squares, Limited Information Maximum Likelihood and Generalized Method of Moments to deal with weak instrument concerns; they use marital status, migration rates in the home village and household registration as instruments while we use the number of helpers in the past 12 months and the number of persons, currently living in the city, to whom you sent

\footnotetext{
${ }^{10}$ To be eligible for UI, one needs to pay UI fees continuously for 1 year. For those who have paid the insurance fees $>=10$ years, they can receive UI up to 24 months; for those $>=5$ and $<10$ years, they can receive UI up to 18 months; for those $>=1$ and $<5$ years, they can receive UI up to 12 months.

11 The updated version, which is extended to 2010, is available at http://ihome.ust.hk/ socholz/SpatialDeflators.html.

${ }^{12}$ The high attrition between the 2008 and 2009 panels (63.6\% for households and $58.4 \%$ for individuals) for the migrant survey precluded our using panel-data estimators to deal with unobserved heterogeneity (Akgüç, Giulietti and Zimmermann 2014)
} 
your greetings in various ways (including visiting/phone call/mail/e-mail, etc.) during the past China Lunar New Year; we also use a decomposition procedure to decompose the pay gap between formal and informal search procedures into differences in observable characteristics and returns to those characteristics. The fact that we find similar results to theirs (detailed subsequently), in terms of both who uses the different search procedures and the magnitude of the selection-corrected returns to using them, suggests that their results and ours are robust with respect to additional data, estimation procedures and instruments.

\section{Results}

\section{Descriptive Statistics}

Table 1 provides the descriptive statistics. As indicated, the average monthly earnings was $1546 \mathrm{RMB}$, average schooling was 9.5 years, average age was 30 years, 29 percent had previous training to do their job, 52 percent were married; only 1 percent reported that their health was poor or very poor; 3 percent reported a physical disability; 81 percent were in a non-local rural hukou of household registration, ${ }^{13}$ and 16 percent were covered by unemployment insurance.

With respect to the method used to find their current job, $60 \%$ reported using an informal method of what the literature refers to as "family and friends" and $40 \%$ reported using a formal method. Of the $60 \%$ who used informal methods, the most common were friends $(29.9 \%)$ and relatives $(18.4 \%)$, followed by a sharp drop to acquaintances $(7.4 \%)$, and family members (4.4\%). For the $40 \%$ who reported using the more formal methods, in descending order of usage, the methods were $10.8 \%$ direct approach, $10.8 \%$ employer recruitment, $7.6 \%$ responding to an advertisement, $6.7 \%$ private employment agency $2.3 \%$ public employment agency, and

\footnotetext{
${ }^{13}$ The other $19 \%$ of migrants in our data set were divided amongst local urban hukou $1 \%$, nonlocal urban hukou $0.5 \%$, and local rural hukou $17.3 \%$.
} 
$1.8 \%$ "other" consisting of found the job by myself, internship introduced by the school, and continued to hold the old job.

What is particularly noticeable for the formal methods of job search is the small proportion of migrant workers ( 2.3 percent) who use any of the public services. In developed countries such public employment agencies are more common and used principally for the unemployed and for less skilled workers. In China, for migrant workers public services are an extremely uncommon procedure. Otherwise, a wide range of both formal and informal procedures are commonly used, with the informal procedures being slightly more common than formal ones.

\section{OLS Regression Results}

As indicated for the worker characteristics in Table 2, the signs and magnitude of the control variables are generally reasonable. ${ }^{14}$ For example, the returns to an additional year of schooling are about 3 percent which is low by international standards but which can be expected for migrant workers where human capital in the form of formal schooling is not likely important. The returns to age exhibit the usual age-earnings profile, increasing for lower levels of age, reaching a maximum and then decreasing at older levels. Specifically, the effect of an additional year of age is 1.9 percent when evaluated at 20 years of age, 0.7 percent at 30 years of experience, with the peak occurring at 35 years of age, and falling slightly thereafter. ${ }^{15}$ Workers who previously received training earn 6.4 percent more than those who did not receive training. Males earn 14.6 percent more than females even after controlling for other wage determining variables. Migrant workers whose health is poor or very poor earn 12.6 percent less than those

\footnotetext{
${ }^{14}$ In log earnings equations, the true proportional change for a categorical independent variable is $\exp (\beta)-1$ where $\beta$ is the estimated coefficient. For low values of $\beta$ the approximation is very close, underestimating the true value by about 0.005 for values of $\beta$ of around 0.10 which is typical for many of our control variables; hence we report the $\beta$ coefficients.

${ }^{15}$ This is calculated as $\partial \ln Y / \partial \mathrm{Age}=\alpha+2 \beta \mathrm{Age}$ where $\alpha$ is the coefficient on the Age variable and $\beta$ the coefficient on Age Squared. The maximum occurs where $\partial \ln Y / \partial A g e=0$ or when Age $=-\alpha / 2 \beta$.
} 
whose health is good or excellent. This likely reflects the importance of good health for the manual labour jobs often done by migrant workers. Perhaps surprisingly, having a physical disability does not affect earnings, perhaps because any negative effect is already captured in the health status variable. Those with a non-local rural hukou earn 3.4 percent more than those of other residential status. Persons who are covered by unemployment insurance had earnings that were 7.5 percent higher than those who are not covered. This may reflect the more formal nature of their employment as well as the possibility that unemployment insurance enables them to search longer for a higher-paying job.

The fact that the control variables generally have the expected sign and are reasonable in magnitude gives some credence to the results for our main variables of interest - the job search procedures used to find their latest job. As indicated in column 1 of the first row of Table 2, the OLS estimates indicate that there is no significant difference in the earnings of those who found their job using informal as opposed to formal job search procedures. However, our subsequent IV estimates suggest that the OLS estimates are subject to severe selection bias from the fact that the choice of job search procedure is endogenous, associated with unobservable factors that affect the choice of informal versus formal procedures and that affect the earnings outcome.

\section{Instrumental Variable Results}

Our first-stage results are presented in Panel A of Table 3, and the descriptive statistics in Panel B of Table 3. As expected, migrants with higher numbers of helpers or persons who they greeted in the city were significantly less likely to use informal job search methods.

As indicated in the top row of Table 2, the large negative and statistically significant coefficients from the three IV estimates (2SLS, LIML and GMM) uniformly indicate that informal job search procedures lead to substantially lower earnings, in the range of 33 to 43 
percent lower, compared to those who use formal job search procedures. In essence, migrant workers who use informal job search procedures have unobservable characteristics (e.g., motivation, initiative, effort), that foster higher earnings. In the case of migrant workers, however, their informal networks are not generally likely to be well-informed about good job prospects in more distant markets. The informal procedures restrict the scope and targeting of job search and are less effective in yielding job matches with higher earnings.

The effects of the control variables are fairly similar under OLS or IV estimation, with some exceptions. The effect of years of schooling becomes smaller under the IV estimates suggesting that those with higher education tend to use the more formal search methods and they also have unobservable characteristics that positively affect earnings. The larger effect of schooling in the OLS estimates was simply reflecting some of the positive effect of these unobservables. Similarly, the effect of training, while still positive, becomes statistically insignificant In essence, the main human capital variables - education and training are reduced in magnitude (and become insignificant in the case of training) under the IV estimates. This suggests that their larger effects under the OLS estimates that did not control for unobserved heterogeneity were reflecting some of the positive effects of the unobservables on earnings. The positive effect of being married increased in magnitude and became statistically significant under the IV estimates.

\section{Decomposition Results}

Table 4 decomposes the pay gap between those who obtained their job using formal search procedures versus informal procedures into two component parts: differences in the usage of the job search procedures (their mean values) and differences in their effect on earnings 
(coefficients). It also sub-decomposes those two components to show the effect of the different pay determining variables on each of these components. ${ }^{16}$

As indicated in the third row, the raw or unadjusted pay advantage (mean pay difference) of those who found their job using formal procedures as opposed to informal procedures is 5 percent. The aggregate decomposition indicates that essentially all of that gap is attributable to the fact that those who have greater endowments of characteristics that positively affect pay tend to use more formal job search procedures. Of that endowment component of the gap, about half ( 0.023 or 46.8 percent of the gap) is attributable to the higher education of those who use formal procedures. Having received training contributes a further 13.4 percent of the endowment component and being covered by unemployment insurance contributes a further 9 percent. The other variables tended to have small or statistically insignificant contributions to the endowment component. In essence, those with higher human capital in the form of education or training tend to use the more formal job search procedures that yield higher earnings.

With respect to the sub-decomposition of the coefficients component, only the returns to years of schooling make a statistically significant contribution to explaining the gap. That is, persons of higher education get a larger return from using formal procedures compared to informal procedures. The fact that it has a positive effect on earnings and yet the portion explained by all coefficients is essentially zero reflects the fact that the positive contribution from education is offset by other negative effects from the coefficients of other variables and especially the large negative effect of the constant term which suggests that informal procedures have a large negative effect on their own.

\footnotetext{
${ }^{16}$ To facilitate interpretation of the quadratic age variable we combine the effect of age and age squared into a single effect as in Boudarbat and Lemieux (2014) and Jann (2008).
} 
In summary, the overall pay advantage of those who found their job using formal procedures as opposed to informal procedures is 5 percent. The most important variable contributing to that overall gap is education. This occurs both because those with more education (which is associated with higher earning) tend to use the more formal procedures, and they get higher returns from the formal procedures compared to informal procedures (which also suggests that they are rationally using the procedures that yield the highest returns to their education).

\section{Summary Observations}

Our OLS estimates indicate that there is no effect on earnings of using informal versus formal job search procedures for migrant workers in China. Our IV results, however, suggest that the OLS estimates are subject to severe selection bias from the fact that the choice of job search procedure is endogenous, associated with unobservable factors that affect the choice of informal versus formal procedures and that affect the earnings outcome. Three different IV estimates designed to deal with this bias indicate that informal procedures (various aspects of family and friends) are associated with earnings that are 33 to 43 percent below the uses of more formal procedures (e.g., public and private employment agencies, applied directly or for an advertised job, employer recruitment). In essence, and as found in Long et al., (2013) migrant workers who use informal job search procedures have unobservable characteristics (e.g., motivation, initiative, effort) that foster higher earnings. However, when they rely on informal job search procedures involving family or friends who may generally be ill-informed about jobs in distant locations, their earnings are substantially reduced. Interpreted through the lens of job search models, the informal procedures restrict the scope and targeting of job search and are less effective in yielding job matches with higher earnings. 
Our decomposition results indicate that the most important variable contributing to pay advantage of those who use formal as opposed to informal procedures is education. This occurs both because those with more education (which is associated with higher earning) tend to use the more formal procedures, and they get higher returns from the formal procedures compared to informal procedures (which also suggests that they are rationally using the procedures that yield the highest returns to their education).

By way of policy recommendations, Long et. al. (2013, p.18) conclude: "A potential policy implication of this is that efforts to increase the access of rural people to urban employment through more formal means - labour exchanges, rural recruitment etc. - may well bring large benefits to them in terms of higher wages." Our results are consistent with those policy recommendations, suggesting that policies to encourage or facilitate migrant workers using more formal job search procedures and reducing barriers that compel them to rely on informal procedures can yield better job matches with higher earnings. Informal procedures can be less costly in time, effort and fees, but the informal social networks available to migrant workers do not appear to lead to better job matches with higher earnings. Whether this also applies to regular workers in China, who may have better informal social networks, is an interesting question that merits further research.

There is always the possibility that the less educated workers could not avail themselves of the formal search methods, and that the search networks may be segregated by education because of the types of jobs that are offered. Even if the less educated could use the formal methods, they may not be qualified for those jobs. In such circumstances policy consideration could be given to subsidizing or increasing the education of migrant workers since more educated migrants use 
the formal networks. As well, policy consideration could be given to providing assistance and guidance for less educated migrants to access and use the formal methods.

On the macro-economic side, better job matches with higher earnings should also facilitate simultaneously reducing unemployment and shortages which would otherwise lead to structural bottlenecks that can inhibit competitiveness and growth. The higher earnings from a better job match also can be a viable poverty reduction strategy and alleviate the vulnerability of migrant workers who generally have little or no protection and could become a source of social instability. These benefits from better job matches are a rare "win-win" strategy for all stakeholders: migrant workers who benefit from the reduced unemployment and higher earnings; employers who benefit from the reduction in shortages; and governments that benefit from the social stability associated with enhanced macro-economic stability and reduced poverty and vulnerability. These are issues of growing policy importance as China makes the transition to a market economy.

\section{REFERENCES}

Addison, J. \& Portugal, P. (2002). Job search methods and outcomes. Oxford Economic Papers, 54:505-533

Akgüç, M., C. Giulietti and K. Zimmermann (2014). The RUMiC longitudinal survey: fostering research on labor markets in China. Journal of Labor and Development. 3: 1-14.

Black, D. (1995). Discrimination in an equilibrium search model. Journal of Labor Economics, 13: 308-333 .

Blackaby, D., Booth, A. \& Frank, J. (2005). Outside offers and the gender pay gap: empirical evidence from the UK academic labour market. Economic Journal, 115: 81-107.

Blau, D. \& Robins, P. (1990). Job search outcomes for the employed and unemployed. Journal of Political Economy, 98:637-655

Boudarbat, B. \& Lemieux, T. (2014). Why are the relative wages of immigrants declining? A distributional approach. Industrial and Labor Relations Review. 67(4): 1127-1165. 
Bowlus, A. (1997). A search interpretation of male-female wage differentials. Journal of Labor Economics, 15: 625-657.

Brandt, L. \& Holz, C. Spatial price differences in China: estimates and implications. Economic Development and Cultural Change. 55(1) 43-86.

Chen Y. (2014). Migrants' job-search in urban China: social networks and the labour market. In Fulong W. et al. Rural Migrants in Urban China: Enclaves and Transient Urbanism. London and New York: Routledge.

Cotton, J. (1988). On the decomposition of wage differentials, Review of Economics and Statistics, 70: 236-243.

Downs, A. \& Gunderson, M. (2002). Job Search and Labor Market Information in Latin America and the Caribbean. Washington: US Department of Labor, Bureau of International Affairs.

Fang, T,, Samnani, A-K, Novicevic, M. \& Bing, M. (2013). Liability-of-foreignness effects on job success of immigrant job seekers. Journal of World Business. 48: 98-109.

Fernandez, R, Castilla, E.J. \& Moore P. (2000) Social capital at work: networks and employment at a phone center. American Journal of Sociology, 105:1288-1356

Gardeazabal, J. \& Ugidos, A. (2005). More on identification in detailed wage decompositions. Review of Economics and Statistics, 86(4): 1034-1036.

Granovetter M. (1973). The strength of weak ties. American Journal of Sociology. 78:1360-80.

Giulietti, C., J. Wahba and Y. Zenou (2014). Strong versus weak ties in migration. IZA Discussion Paper No. 8089.

Hanser A. (2002). Youth job searches in urban China: the use of social connections in a changing labor market. In Gold T. et al. Social Connections in China: Institutions, Culture, and the Changing Nature of Guanxi. Cambridge University Press.

Holzer, H. (1988). Search method use by unemployed youth. Journal of Labor Economics, 6:120

Jann, B. (2008). The Blinder-Oaxaca decomposition for linear regression models. The Stata Journal, 8: 453-479.

Kahn, L. \&, Low, S. (1990). The demand for labor market information. Southern Economic Journal. 56:1044-1058

Kuhn, P. \&, Skuterud, M. (2004). Internet job search and unemployment durations. American Economic Review, 94:218-232 
Lai, D. \& Yongpo, T. (2005). An explanation for "educated unemployment" in China. Economic Research Journal, 11: 111-119.

Long W. et. al (2013). Job contact networks and wages of rural-urban migrants in China. IZA Discussion Paper No. 7577.

Lu, Z. \& and Song, S. (2006). Rural-urban migration and wage determination: the case of Tianjin, China. China Economic Review. 17: 337-345.

Mortensen, D.T. (1986). Job search and labor market analysis. In: Ashenfelter, O. \& Layard, R. (eds). Handbook of labor economics. Elsevier, Amsterdam, pp 849-919

Mouw T. (2003). Social capital and finding a job: do contacts matter? American Sociological Review. 68: 868-898.

Murray, M (2006). Avoiding invalid instruments and coping with weak instruments. Journal of Economic Perspectives. 20: 111-132.

Neumark, D. (1988). Employers' discriminatory behavior and the estimation of wage discrimination. Journal of Human Resources, 23: 279-295.

Oaxaca, R. (1973). Male-female wage differentials in urban labor markets. International Economic Review, 14: 693-709.

Oaxaca, R. L., \& Ransom, M. R. (1994). On discrimination and the decomposition of wage differentials. Journal of Econometrics, 61(1), 5.

Osberg, L. (1993). Fishing in different pools: job-search strategies and job-finding success in Canada in the early 1980s. Journal of Labor Economics, 11:348-386

Qu, Z \& Zhao, Z. (2011). Evolution of the Chinese rural-urban migrant labour market from 2002 to 2007. IZA Discussion paper 5421.

Rees, A. (1966). Information networks in labor markets. American Economic Review, 56:559566

Saks, A. (2005). Job search success: A review and integration of the predictors, behaviors, and outcomes". In Career development and counseling: Putting theory and research to work. Hoboken, NJ, US: John Wiley \& Sons, pp. 155-179.

Schwab, D., Rynes, S., \& Aldag, R. (1987). Theories and research on job choice. In Rowland and Ferris (eds.) Research in personnel and human management". Greenwich, CT: JAI Press, Inc., 129-166.

Solinger, D. (1999). Contesting citizenship in urban China: peasants, migrants, the state and the logic of market. Berkeley: University of California Press. 
Stevens, B. (2009). The internet and job search. In D. Autor (ed). Studies of Labor Market Intermediation. University of Chicago Press, pp. 67-86.

Stock, J. \& Yogo, M. (2005). Testing for weak instruments in linear IV regression. In Andrews, D. Identification and Inference for Econometric Models. New York: Cambridge University Press, pp. 80-108.

Van der Muelen Rodgers, Y. (2006). A primer on wage gap decompositions in the analysis of labor market discrimination. In Rodgers, William M. III. (ed). Handbook on the economics of discrimination. Northampton, MA: Edward Elgar Publishing, pp. 11-28.

Wang W. (2008). Hukou and graduates' job search in China, Asian Economic Journal, 22 (1): 123.

$\mathrm{Xu}, \mathrm{F}$. (2000). Women migrant workers in China's economic reform. New York: St. Martin's Press.

$\mathrm{Xu}, \mathrm{F}$. (2012). Looking for work in post-socialist China: governance, active job seekers and the new Chinese labour market. New York: Routledge, 2012.

Yun, M. (2005). A simple solution to the identification problem in detailed wage decompositions. Economic Inquiry, 43: 766-769. 
Table 1 Summary Statistics of Migrant Worker Age 16-64

\begin{tabular}{|c|c|c|c|c|}
\hline Variable & Mean & S.D. & Min. & Max. \\
\hline \multicolumn{5}{|l|}{ Workers' characteristics } \\
\hline Earnings (monthly, RMB) & 1546.02 & 741.37 & 120 & 10655.9 \\
\hline Years of schooling & 9.49 & 2.45 & 1 & 20 \\
\hline Age & 29.65 & 9.91 & 16 & 64 \\
\hline Age squared/100 & 9.77 & 6.84 & 2.56 & 40.96 \\
\hline Received training & .29 & .45 & 0 & 1 \\
\hline Male & .61 & .49 & 0 & 1 \\
\hline Married & .52 & .50 & 0 & 1 \\
\hline Poor health & .01 & .11 & 0 & 1 \\
\hline Physical disability & .03 & .17 & 0 & 1 \\
\hline Non-local rural hukou & .81 & .39 & 0 & 1 \\
\hline Unemployment insurance & .16 & .36 & 0 & 1 \\
\hline Job-finding methods (\%) & 100.00 & & & \\
\hline Informal & $(60.0)$ & & & \\
\hline Family members & 4.41 & & & \\
\hline Relatives & 18.36 & & & \\
\hline Friends & 29.90 & & & \\
\hline Acquaintance & 7.36 & & & \\
\hline Formal & (40.0) & & & \\
\hline Public agency & 2.31 & & & \\
\hline Private agency/job fair & 6.72 & & & \\
\hline Advertisement & 7.63 & & & \\
\hline Direct approach & 10.78 & & & \\
\hline Employer recruitment & 10.75 & & & \\
\hline Other & 1.79 & & & \\
\hline Observations & 8,155 & & & \\
\hline
\end{tabular}

Note: We restrict our analysis to age 16-64 individuals who are full-time wage workers and report positive earnings. Self-employed, employers, part-time workers, temporary jobs, in school students, family workers without pay are excluded.

Earnings has been adjusted for inflation and accounted for the differing living costs among provinces by applying the PPP-adjusted deflator developed by Brandt and Holz (2006). To reduce the effect of outliers, workers' monthly earnings greater than $20,000 \mathrm{rmb}$ or less than $100 \mathrm{rmb}$ are excluded.

The variables Male, Married, Physical disability, Non-local, rural hukou, Unemployment insurance, and Received training are 1/0 dummies. Poor health is a dummy variable which equals 1 if the worker answers 2: Poor, and 1: Very poor. Public employment agency includes "Arranged by the government", "Through employment agent run by government", and "Through community employment service station". Advertisement includes applied through internet. Other includes "Found the job by himself", "Internship introduced by school", "Introduced by the school" and "Continued to hold the old job." 
Table 2 OLS, 2SLS, LIML and GMM estimates

\begin{tabular}{|c|c|c|c|c|c|c|c|c|}
\hline \multirow{2}{*}{$\begin{array}{l}\text { Dependent Variable: } \\
\text { Log Earnings } \\
\text { Variable }\end{array}$} & \multicolumn{2}{|c|}{ OLS } & \multicolumn{2}{|c|}{ 2SLS } & \multicolumn{2}{|c|}{ LIML } & \multicolumn{2}{|c|}{ GMM } \\
\hline & Coeff. & $\begin{array}{c}\text { Cluster } \\
\text { robust } \\
\text { std. err. }\end{array}$ & Coeff. & $\begin{array}{c}\text { Cluster } \\
\text { robust } \\
\text { std. err. }\end{array}$ & Coeff. & $\begin{array}{c}\text { Cluster } \\
\text { robust } \\
\text { std. err. }\end{array}$ & Coeff. & $\begin{array}{c}\text { Cluster } \\
\text { robust } \\
\text { std. err. }\end{array}$ \\
\hline \multicolumn{9}{|l|}{ Job-finding method } \\
\hline Informal & .002 & .007 & $-.410^{* *}$ & .186 & $-.427^{* *}$ & .181 & $-.331^{*}$ & .177 \\
\hline \multicolumn{9}{|l|}{ Workers' characteristics } \\
\hline Years of schooling & $.027^{* * *}$ & .003 & $.012^{* *}$ & .006 & $.013^{* * *}$ & .005 & $.016^{* * * *}$ & .005 \\
\hline Age & $.045^{* * *}$ & .005 & $.037^{* * *}$ & .005 & $.039^{* * *}$ & .004 & $.041^{* * *}$ & .004 \\
\hline Age sq./100 & $-.064^{* * *}$ & .007 & $-.053^{* * *}$ & .007 & $-.056^{* * *}$ & .006 & $-.058^{* * *}$ & .006 \\
\hline Received training & $.064^{* * *}$ & .011 & $.032^{*}$ & .017 & $.034^{* *}$ & .016 & $.038^{* *}$ & .016 \\
\hline Male & .144 & .012 & $.140^{* * *}$ & .014 & $.146^{* * * *}$ & .014 & $.142^{* * * *}$ & .013 \\
\hline Married & .016 & .013 & $.033^{* *}$ & .012 & $.038^{* * *}$ & .012 & $.033^{* * *}$ & .012 \\
\hline Poor health & $-.126^{* *}$ & .043 & $-.146^{* * *}$ & .051 & $-.162^{* * *}$ & .051 & $-.145^{* * *}$ & .051 \\
\hline Physical disability & -.006 & .028 & -.006 & .028 & .010 & .026 & .005 & .026 \\
\hline Non-local rural hukou & $.004^{*}$ & .001 & $.002^{* * *}$ & .001 & $.002^{* * *}$ & .001 & $.002^{* * *}$ & .001 \\
\hline Unempl. insurance & $.075^{* * *}$ & .018 & $.070^{* * *}$ & .024 & $.057^{* *}$ & .024 & $.067^{* * *}$ & .024 \\
\hline Industry & \multicolumn{2}{|c|}{ YES } & \multicolumn{2}{|c|}{ YES } & \multicolumn{2}{|c|}{ YES } & \multicolumn{2}{|c|}{ YES } \\
\hline Occupation & \multicolumn{2}{|c|}{ YES } & \multicolumn{2}{|c|}{ YES } & \multicolumn{2}{|c|}{ YES } & \multicolumn{2}{|c|}{ YES } \\
\hline City & \multicolumn{2}{|c|}{ YES } & \multicolumn{2}{|c|}{ YES } & \multicolumn{2}{|c|}{ YES } & \multicolumn{2}{|c|}{ YES } \\
\hline Year & \multicolumn{2}{|c|}{ YES } & \multicolumn{2}{|c|}{ YES } & \multicolumn{2}{|c|}{ YES } & \multicolumn{2}{|c|}{ YES } \\
\hline Weak id test & \multicolumn{2}{|c|}{-} & \multicolumn{2}{|c|}{9.319} & \multicolumn{2}{|c|}{9.319} & \multicolumn{2}{|c|}{9.319} \\
\hline \multirow[t]{2}{*}{ Hansen $\mathrm{J}$ statistic } & \multicolumn{2}{|c|}{-} & \multicolumn{2}{|c|}{1.739} & \multicolumn{2}{|c|}{1.998} & \multicolumn{2}{|c|}{1.739} \\
\hline & \multicolumn{2}{|c|}{$.341^{a}$} & $(.1$ & & & & $(.1$ & \\
\hline Observations & 8,1 & & 8,1 & & & & 8,1 & \\
\hline
\end{tabular}

Note: The variable "Informal" is instrumented. Two instrumental variables are (1) number of helpers in the past 12 months and (2) number of persons, currently living in the city, to whom you sent your greetings in various ways (including visiting/phone call/mail/e-mail, etc.) during the past China Lunar New Year.

${ }^{* * * *},{ }^{* *}$ and ${ }^{*}$ indicate that the estimate is statistically significant at the 1,5 and $10 \%$ levels, respectively.

For 2SLS and GMM, weak identification test reports Cragg-Donald Wald F statistic with Stock-Yogo weak ID test critical values 19.93 at $10 \%$ maximal IV size; 11.59 at $15 \%$ maximal IV size; 8.75 at $20 \%$ maximal IV size; 7.25 at 25\% maximal IV size. For LIML, weak identification test reports Cragg-Donald Wald F statistic with Stock-Yogo weak ID test critical values 8.68 at 10\% maximal IV size; 5.33 at $15 \%$ maximal IV size; 4.42 at $20 \%$ maximal IV size 3.92 at $25 \%$ maximal IV size. Chi-sq p-values are in parentheses.

$a: \mathrm{R}^{2}$ for the OLS regression. 
Table 3 First stage regression results and summary statistics of IV

Dependent Variable:

Informal (Job-finding method)

Variable

Coeff.

Cluster robust std. err.

\section{A. First stage results}

\section{Instrumental variable}

Helpers

Persons greeted living in the city

$\begin{array}{ll}-.0015^{* * * *} & .0004 \\ -.0015^{* * *} & .0005\end{array}$

Workers' characteristics

Years of schooling

$-.022^{* * *}$

.003

Age

Age sq./100

$-.014^{* *}$

.006

Received training

$.021^{* * * *}$

.008

Male

$-.061^{* * * *}$

.013

Married

$-.014$

.013

Poor health

$.029^{*}$

.017

Physical disability

$-.031$

.038

Non-local rural hukou

$-.018$

.040

Unempl. Insurance

$.002^{* * *}$

.001

$-.040$

.035

Industry

YES

Occupation

YES

City

YES

Year

YES

F-statistics

9.319

Observations

8,155

\section{B. Summary statistics of IVs}

IV

Number

\begin{tabular}{ccccccccccc}
\multicolumn{10}{c}{$(\%)$} \\
\hline \multirow{2}{*}{ Helpers } & Mean & S.D. & 0 & 1 & 2 & 3 & 4 & 5 & $6-9$ & $>9$ \\
& 3.04 & 4.68 & $(20.28)$ & $(19.16)$ & $(18.73)$ & $(18.68)$ & $(4.24)$ & $(7.61)$ & $(4.52)$ & $(6.79)$ \\
\hline People & Mean & S.D. & 0 & $1-10$ & $11-20$ & $21-30$ & $31-40$ & $41-50$ & $51-60$ & $>60$ \\
greeted & 11.94 & 17.32 & $(13.18)$ & $(58.00)$ & $(15.90)$ & $(5.52)$ & $(2.12)$ & $(1.74)$ & $(1.02)$ & $(2.51)$ \\
\hline
\end{tabular}

Note: the first stage regression results are the same for 2SLS, LIML, and GMM. "Helpers" denotes the number of helpers in the past 12 months and "People greeted living in the city" denotes the number of persons, currently living in the city, to whom you sent your greetings in various ways (including visiting/phone call/mail/e-mail, etc.) during the past China Lunar New Year.

${ }^{* * * *},{ }^{* *}$ and ${ }^{*}$ indicate that the estimate is statistically significant at the 1,5 and $10 \%$ levels, respectively. 
Table 4 Earnings gap decomposition of migrants using formal vs. informal job search methods

\begin{tabular}{|c|c|c|c|}
\hline & Coefficient & $\begin{array}{c}\text { Cluster } \\
\text { robust } \\
\text { std. err. }\end{array}$ & $\begin{array}{c}\text { Contribution } \\
(\%)\end{array}$ \\
\hline \multicolumn{4}{|l|}{ Panel A } \\
\hline Log earnings of using formal method workers & $7.251^{* * *}$ & .043 & - \\
\hline Log earnings of using informal method workers & $7.202^{* * *}$ & .044 & - \\
\hline Earnings differential & $.050^{* * *}$ & .016 & 100.00 \\
\hline \multicolumn{4}{|l|}{ Aggregate decomposition } \\
\hline Explained by endowments & $.050^{* * *}$ & .014 & 101.35 \\
\hline Explained by coefficients & -.001 & .007 & -1.35 \\
\hline \multicolumn{4}{|l|}{ Panel B } \\
\hline \multicolumn{4}{|l|}{ Detailed decomposition } \\
\hline \multicolumn{4}{|l|}{ Due to difference in endowments } \\
\hline Years of schooling & $.023^{* * *}$ & .004 & 46.81 \\
\hline Age & .001 & .003 & 2.79 \\
\hline Received training & $.007^{* * *}$ & .002 & 13.43 \\
\hline Married & .000 & .001 & .04 \\
\hline Poor health & -.000 & .000 & -.21 \\
\hline Physical disability & -.000 & .000 & -.05 \\
\hline Non-local rural hukou & .001 & .001 & 1.54 \\
\hline Unemployment insurance & $.005^{*}$ & .002 & 9.32 \\
\hline \multicolumn{4}{|l|}{ Due to difference in coefficients } \\
\hline Years of schooling & $.047 *$ & .028 & 94.05 \\
\hline Age & .120 & .096 & 242.81 \\
\hline Received training & .001 & .003 & 2.25 \\
\hline Married & -.000 & .000 & -.26 \\
\hline Poor health & .001 & .054 & 2.74 \\
\hline Physical disability & -.034 & .025 & -69.29 \\
\hline Non-local rural hukou & -.009 & .011 & -18.67 \\
\hline Unemployment insurance & -.008 & .011 & -16.15 \\
\hline Constant & -.154 & .137 & -311.35 \\
\hline Observations & \multicolumn{2}{|c|}{8,155} & \\
\hline
\end{tabular}

Note: Observations of using formal method and informal method migrant workers are 3,260 and 4,895, respectively. Difference $=\log$ earnings of using formal method workers - log earnings of using informal method workers.

${ }^{* * *},{ }^{* *}$ and ${ }^{*}$ indicate that the estimate is statistically significant at the 1,5 and $10 \%$ levels, respectively.

Standard errors are adjusted for 15 clusters in city. There are 25 occupation dummies, 29 industry dummies, 3 region dummies, and 2 year dummies. Based on the normalization method in Yun (2005) and Gardeazabal and Ugidos (2004) to address the problem that coefficients attributed to the dummy variables are not invariant to the choice of the omitted reference, the estimates of the dummy variables are combined effects of the dummy variable and the omitted reference category. 
Appendix Table 1 Summary statistics of migrant workers by contract type

\begin{tabular}{|c|c|c|c|c|}
\hline \multirow[b]{2}{*}{ Variable } & \multicolumn{4}{|c|}{ Contract type } \\
\hline & Permanent & Long term & Short term & $\begin{array}{c}\text { No contract } \\
\text { temporary }\end{array}$ \\
\hline \multicolumn{5}{|l|}{ Workers' characteristics } \\
\hline \multirow[t]{2}{*}{ Earnings (monthly, RMB) } & 1586.11 & 1669.85 & 1510.81 & 1380.53 \\
\hline & $(850.95)$ & $(741.17)$ & $(682.98)$ & $(656.86)$ \\
\hline \multirow[t]{2}{*}{ Years of schooling } & 9.44 & 9.89 & 9.69 & 8.86 \\
\hline & $(2.54)$ & $(2.40)$ & $(2.28)$ & $(2.42)$ \\
\hline \multirow[t]{2}{*}{ Age } & 29.76 & 29.58 & 29.01 & 30.20 \\
\hline & $(10.55)$ & $(9.11)$ & $(9.53)$ & $(10.85)$ \\
\hline \multirow[t]{2}{*}{ Age squared/100 } & 9.97 & 9.58 & 9.32 & 10.30 \\
\hline & $(7.38)$ & $(6.19)$ & $(6.41)$ & $(7.60)$ \\
\hline \multirow[t]{2}{*}{ Received training } & 0.26 & 0.33 & 0.28 & 0.19 \\
\hline & $(0.44)$ & $(0.47)$ & $(0.45)$ & $(0.39)$ \\
\hline \multirow[t]{2}{*}{ Male } & 0.62 & 0.63 & 0.55 & 0.59 \\
\hline & $(0.49)$ & $(0.48)$ & $(0.50)$ & $(0.49)$ \\
\hline \multirow[t]{2}{*}{ Married } & 0.51 & 0.54 & 0.49 & 0.52 \\
\hline & $(0.50)$ & $(0.50)$ & $(0.50)$ & $(0.50)$ \\
\hline \multirow[t]{2}{*}{ Poor health } & 0.01 & 0.01 & 0.01 & 0.02 \\
\hline & $(0.08)$ & $(0.08)$ & $(0.11)$ & $(0.14)$ \\
\hline \multirow[t]{2}{*}{ Non-local rural hukou } & 0.84 & 0.85 & 0.81 & 0.75 \\
\hline & $(0.37)$ & $(0.36)$ & $(0.39)$ & $(0.43)$ \\
\hline \multirow[t]{2}{*}{ Unempl. insurance } & 0.13 & 0.28 & 0.15 & 0.02 \\
\hline & $(0.33)$ & $(0.45)$ & $(0.36)$ & $(0.15)$ \\
\hline \multirow[t]{2}{*}{ Physical disability } & 0.03 & 0.03 & 0.03 & 0.03 \\
\hline & $(0.18)$ & $(0.17)$ & $(0.16)$ & $(0.16)$ \\
\hline \multirow[t]{2}{*}{ Job tenure (year) } & 3.37 & 3.53 & 2.67 & 2.77 \\
\hline & $(4.28)$ & $(3.80)$ & $(3.63)$ & $(4.04)$ \\
\hline Job-finding methods [\%] & 100.00 & 100.00 & 100.00 & 100.00 \\
\hline Informal & {$[57.90]$} & {$[56.05]$} & {$[60.10]$} & {$[66.25]$} \\
\hline Family members & 5.03 & 4.16 & 4.54 & 4.45 \\
\hline Relatives & 20.62 & 17.97 & 15.77 & 19.35 \\
\hline Friends & 24.88 & 27.68 & 30.10 & 34.57 \\
\hline Acquaintance & 7.36 & 6.24 & 9.69 & 7.88 \\
\hline Formal & {$[42.10)$} & [43.95] & [39.90] & {$[33.75]$} \\
\hline Public agency & 5.03 & 2.41 & 2.58 & 1.01 \\
\hline Private agency/job fair & 3.68 & 10.34 & 7.42 & 3.04 \\
\hline Advertisement & 9.58 & 8.41 & 7.84 & 5.70 \\
\hline Direct approach & 10.94 & 10.10 & 9.28 & 12.45 \\
\hline Employer recruitment & 11.13 & 10.79 & 12.16 & 9.56 \\
\hline Other & 1.74 & 1.90 & 0.62 & 1.99 \\
\hline Observations & 1,033 & 3,317 & 970 & 2,563 \\
\hline
\end{tabular}

Note: standard deviations are in parentheses. 
Appendix Table 2 Multinomial logit model estimates

\begin{tabular}{|c|c|c|c|c|c|c|}
\hline $\begin{array}{l}\text { Dependent Variable: } \\
\text { Contract type }\end{array}$ & Lons & erm & Sho & term & $\begin{array}{l}\text { No } \\
\text { tem }\end{array}$ & $\begin{array}{l}\text { tract } \\
\text { rary }\end{array}$ \\
\hline Variable & Coeff. & $\begin{array}{c}\text { Cluster } \\
\text { robust } \\
\text { std. err. }\end{array}$ & Coeff. & $\begin{array}{c}\text { Cluster } \\
\text { robust } \\
\text { std. err. }\end{array}$ & Coeff. & $\begin{array}{l}\text { Cluster } \\
\text { robust } \\
\text { std. err. }\end{array}$ \\
\hline Job-finding method & & & & & & \\
\hline Informal & 089 & .073 & $.195^{* *}$ & .099 & $.229^{* * * *}$ & .080 \\
\hline Workers' characteristics & & & & & & \\
\hline Years of schooling & $.058^{* *}$ & .026 & .039 & .032 & $-.068^{* * *}$ & .017 \\
\hline Age & $.112^{* * *}$ & .043 & $.085^{* *}$ & .035 & .044 & .030 \\
\hline Age sq./100 & $-.164^{* * *}$ & .058 & $-.123^{* * *}$ & .048 & -.056 & .038 \\
\hline Received training & .173 & .132 & -.014 & .227 & $-.481^{* * *}$ & .157 \\
\hline Male & -.031 & .080 & $-.339^{* * * *}$ & .096 & $-.195^{* * *}$ & .065 \\
\hline Married & .007 & .102 & -.196 & .147 & $-.207^{* *}$ & .101 \\
\hline Poor health & .018 & .432 & .473 & .457 & $.825^{* * * *}$ & .295 \\
\hline Physical disability & -.038 & 287 & -.243 & .260 & -.223 & .227 \\
\hline Non-local rural hukou & -.003 & .003 & -.005 & .004 & -.007 & .005 \\
\hline Unempl. insurance & $.935^{* * *}$ & .119 & .188 & .123 & $-1.60^{* * *}$ & .246 \\
\hline Industry & & & & & & \\
\hline Occupation & & & & & & \\
\hline City & & & & & & \\
\hline Year & & & & & & \\
\hline Pseudo $\mathrm{R}^{2}$ & & & & & & \\
\hline Observations & & & & & & \\
\hline
\end{tabular}

Note: the base outcome variable is permanent contract. Standard errors are adjusted for 15 clusters in city. ${ }^{k * * * *}$ and

* indicate that the estimate is statistically significant at the 1,5 and $10 \%$ levels, respectively. 